UDK 37.07

DOI 10.22363/2312-8631-2017-14-1-76-82

\title{
THE PROJECT OF ADMINISTRATIVE AND METHODICAL MANAGEMENT AUTOMATIZATION IN EDUCATIONAL INSTITUTION AS A TERM OF EDUCATION PROCESS QUALITY IMPROVEMENT
}

\author{
A.I. Yatsenko \\ Peoples' Friendship University of Russia \\ Miklukho-Maklaya str., 6, Moscow, Russia, 117198
}

\begin{abstract}
The article is devoted to the practice of information technologies implementation in the educational process according to the condition of educational informatization. The actuality of main article concept is confirmed by the trend of widespread introduction of information technologies in education both from the state and from business. Taking into account the increased attention to acquiring of high results in the educational process, the information technology tools allows to significantly improve the quality of education. In this regard, the article provides examples of various information systems using in order to administer educational process, their advantages and disadvantages. In consequence, the author formulates the problem of lack of integrated information systems. However, the development of information technologies is oriented towards a worldwide network, which has an access to a vast audience of users. Educational institutions are involved in the electronic process supported by an electronic environment of the educational development. As a result of the issue study above and the modern trends review in the article the author suggests a project description of educational organization management optimization with the help of the integrated information system use on the Internet.
\end{abstract}

Key words: information technologies, information system, informatization of the education, educational process, educational institution, electronic environment

Modern conditions of the society development are characterized by continuous growth in creation and use of information technologies (IT). The progress provides high level of information development in all spheres of the society, including education.

State policy in the sphere of education in the Russian Federation launches many reforms and programs aimed at the solution of actual educational problems at the Federal, regional and municipal levels. Currently government actively implements actions for:

- infrastructure development of unified educational information space,

- development of electronic educational resources,

- measures to improve employees and teachers skills in the sphere of IT,

- measures to introduce IT in the educational process and practice of educational complex management.

The application of IT in education can be limited by two areas: the use of IT in the process of knowledge transfer and application of technologies in educational processes management. Considering the increasing demands for education quality the main basics of the educational process are forms and methods of educational processes organization, improvement of the learning content, as well as modernization of the education system. 
In order to achieve these objectives, the priority in the development is the IT introduction in the educational management. However, this direction remains unanswered. Therefore, the management of educational institutions forced to use outdated methods of curricula constructing, educational reporting and communication with all participants in the educational process. Also high rates of informatization does not lead to the effective IT use in a school administration. This is partly caused by the lack of software for an educational administration as well as by insufficient financing. Thus, the decision of the proper IT use in the framework of informatization in education is under the question.

Russian scientists pay a great attention to the application of information systems in the educational process. K. Colin is considering priorities for the use of information systems. A.V. Baklanov analyzes the current state and main problems of the educational management informatization. M.I. Bakaeva refers to the basic automated process control systems in education, which help to achieve the goals of educational management. The consideration of the scientific papers provides an idea that the use of information systems for management of an educational institution is an integral part of the educational informatization in general and requires deliberate actions.

According to the topic relevance, the main objective of this article is to examine information systems that is used for the organization of educational process, as well as the challenges and opportunities of their application.

The goals of the informatization are achieved using such tools as educational information resources, which are mainly operating on the Internet.

Currently the Internet includes many educational resources that are designed to different objectives in the educational system. Examples of these resources are:

- educational Internet portals;

- service computer software;

- electronic publication;

- e-assessment tools and measurement of the learning outcomes;

- communicational resources for the information exchange between participants in the educational process;

- electronic libraries, etc. [1]

IT largely allow to obtain reliable and prompt information about the current situation in the educational process. The main communicators in the information space of an educational organization are administration, teachers, students and parents. The administration in this aspect is the main coordinator of information with following functions [2]:

- planning of the educational process;

- quality control of the educational process.

Currently, the main reference of the educational informatization implementation in the educational institution management is the creation of the electronic educational environment where all participants can communicate with each other by the means of IT (Fig. 1).

The scheme provides a complete picture of the importance of administrative components development in the educational institution, because this segment of the educational environment forms the basis of the educational process and specify access to IT. 


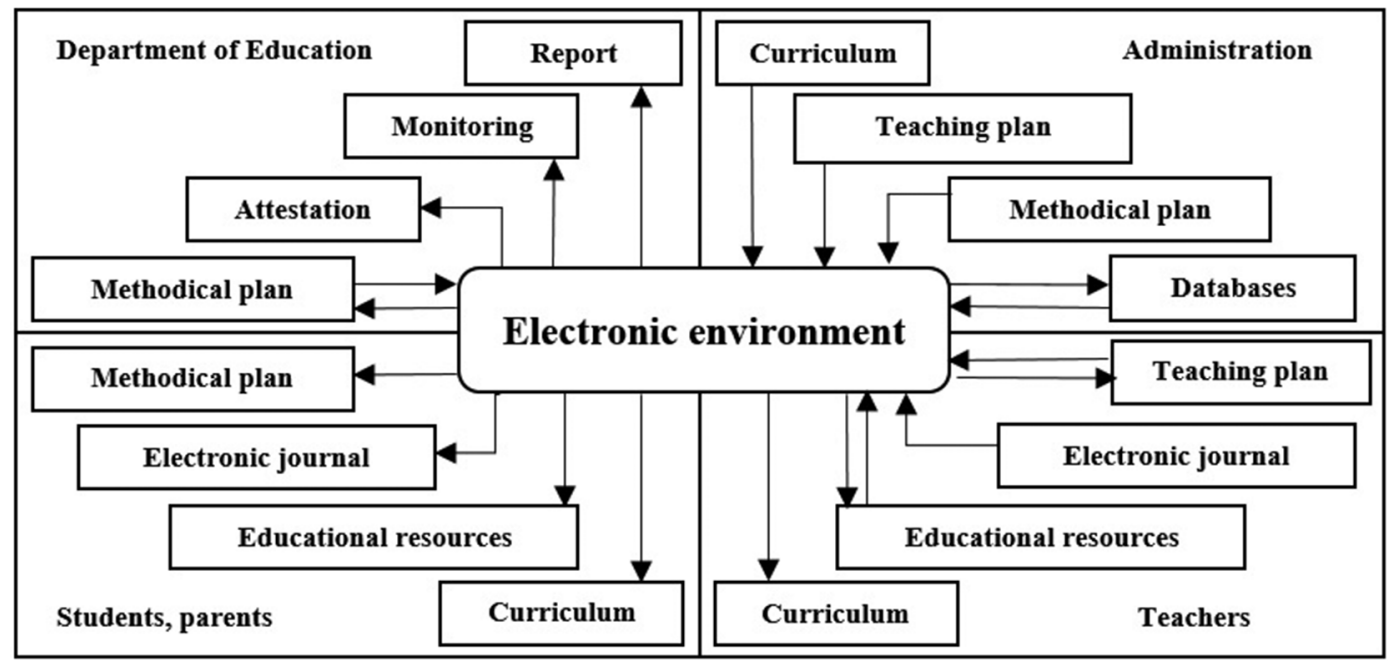

Fig. 1. The scheme of an educational institution electronic environment

Almost each function of the educational institution administration is possible to be optimized using IT. During formation of the educational process, Schools administrations widely use software products for scheduling, which considers the characteristics of the curricula, sanitary norms, replacements graphics etc.

Regarding the function of the educational process quality control, currently programmers develop automated management information system. Its allow based on background information to prepare reports on progress, absences, analyze the operation of an educational institution with the help of quality indicators.

However, with a huge number of programs for optimization of managerial activities, there is no common element that allows to aggregate data from databases including: curriculum, staff, students, information about an academic competition. Employees of an educational institution are forced to make the same information in different information systems several times. It influences the time of performance.

Let is review the developers' programs for educational process management automatization [3].

«KM-School», «1C: Education», «Open College», «The Federal center of information and educational resources» represent a content system, focused on quality content of educational process with information resources and mechanisms for efficient organization of work in an educational institution.

«1C: School management», «Avers», «1C: Chronograph» allow to organize the workflow process and information transfer in an educational institution, to automate financial and economic activities, work with staff and students.

«Net School», «School» are the most common programs of the management automatization in an educational institution, allowing to make necessary reports and to ensure effective interaction of all participants of the educational process.

Such variety of information systems demonstrates that each of them is designed for specific functions in the educational process: accounting, human resources, monitoring of the progress, workflow automation, etc. In this regard, educational institutions use in 
their practice several software products. This complicates the process of the system implementation, increases costs, and forces of employees to adapt to the structure of the new implemented system.

For example, Moscow educational complex «School №2070» includes twelve divisions. Administration and staff use the following software products: GIS «Contingent»; «1C: Management of school»; «Nika-Luxe 6»; the Database of the single integrated information system; AIS «Olympics», UAIS «Budget accounting»; «Electronic log and diary» etc. Thus, maintaining such number of information systems institution focuses employees on the work with each system separately, thus distracting from the main educational process.

Analyzing all communications that occur in the process of transferring data between programs it is reflected the possibility of sending data between several software products (Contingent, 1C, AIS «Olympics», Electronic journal). At the same time, for example, information, which is necessary to ECIS and Nika-Luxe, does not interact with other programs.

The solution of this problem is the creation of such software product that will cover the maximum functions in the educational process.

Considering specifics of an educational institutions activity, architecture of an information system must match the internal and external user requests. Now information systems are represented in different types: two-tier client-server architecture, three-tier client-server architecture, access model via the Internet [4]. Analyzing the advantages and disadvantages of each model, it can be noted that the architecture via the Internet is largely contribute to more active implementation and use of the system from the dynamic and unstable educational environment.

Designing is based on the realization of the project goals. In this case, the aim of the project is to solve the task focused on ensuring of the methodical part of work during the launch and further operation [5]:

- functionality: maintaining a database of staff and students, curriculum, schedule development, monitoring of the progress, evaluation of the quality of teachers ' work; design of teaching programs; maintenance of financial and economic activities, etc.

- throughput: access to the resource by all participants of the educational process (administration, staff, students and parents, departments);

- time waiting for a response from an information system on the request;

- uninterrupted work mode;

- appropriate level of data security;

- interface usability for different users.

The information system design is impossible without a functioning set of integrated software products, which can accumulate data to provide the necessary protected information to different user groups.

The development of such integrated software is foreseen in the plans of a Nika-Soft company, providing software for scheduling in institutions of general and secondary professional education. According the project the company develops an information system based on the transfer of current software to the Internet with the implementation of additional functions to the scheduling. The purpose of these changes was the need to develop such software, which will combine the basic administrative and methodical 
functions on the Internet. Figure 2 shows an example of transfer and software use by educational institutions offline.

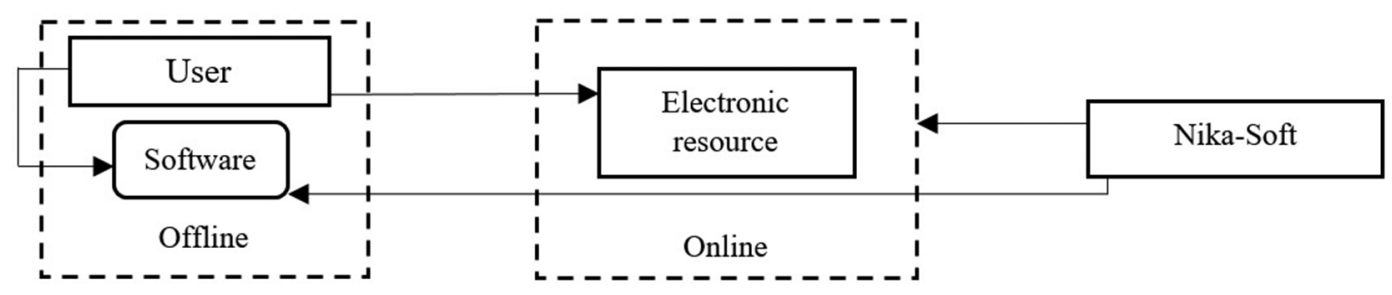

Fig. 2. The scheme of the current software use

Figure 3 is a plan scheme of the user and software synergy considering the implementation of the whole information system of an educational institution to the Internet.

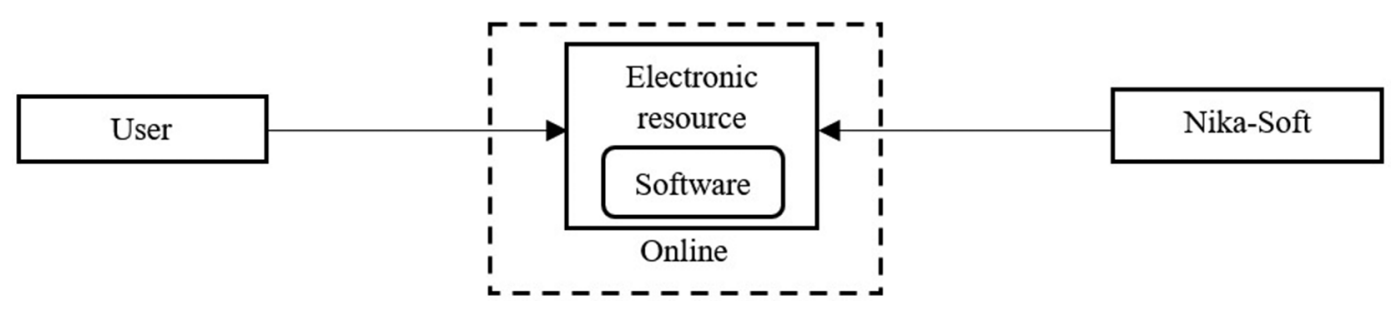

Fig. 3. The planning scheme of the software use

The conclusion: The creation and implementation of a planned software product is intended to solve the following problems:

- the creation of a unified information system of an educational institution;

- rational and efficient use of data;

- optimization of the teachers' work with the system in favor of the educational process;

- usability of the main information system for a work;

- more detailed reporting on a work;

- maximum availability of all participants of the educational process to the information system.

Thus, the creation of the integrated information system on the Internet will allow to all participants to ensure access to necessary information at any time, thereby concentrating the basic human and time resources on the core function of education - learning.

\section{REFERENCES}

[1] Obrazovatelnye resursy seti internet dlya osnovnogo obshchego i srednego (polnogo) obshchego obrazovaniya [Educational Internet resources for basic general and secondary education]. M.: Federalnoe agentstvo po obrazovaniyu [Federal Agency for education]. 2006.

[2] Marzhina R.A. Obzor informatsionnykh tekhnologiy v upravlenii obshcheobrazovatelnoy shkoloy [Overview of information technology in the management of secondary school] Teoreticheskiye $i$ prikladnye aspecty sovremennoy nauki [Theoretical and applied aspects of modern science]. 2014. No. 5 (3). Pp. 94-97.

[3] Magomadova Z.S. Ispolzovaniye informatsionnykh system vobrazovatelnom prostranstve sovremennoy obshcheobrazovatelnoy shkoly [The use of information systems in educational space of modern 
secondary school]. Mir nauki, kultury, obrazovaniya [The world of science, culture, education]. 2015. No. 2 (51). Pp. 90-91.

[4] Sovetov B.Y., Vodyakho A.I., Dubenetskiy V.A., Tsekhanovskiy V.V. Arkhitektura informatsionnykh system [The architecture of information systems]: uchebnik. M.: Akademiya, 2012. 288 p.

[5] Dudina I.P., Yarygin A.N. Proektirovanie informatsionnogo prostranstva obrazovatelnogo uchrezhdeniya [The design of the information space of an educational institution]. Vektor nauki Tolyattinskogo gosudarstvennogo universiteta. Seriya: Pedagogika, psikhologiya [Vector of science of Togliatti state University. Series: Pedagogics, psychology]. Tolyatti: TGU, 2014. No. 3. Pp. 91-93.

(C) Yatsenko A.I., 2017

Article history:

Received: 2 November 2016

Accepted: 29 November 2016

For citation:

Yatsenko A.I. The project of administrative and methodical management automatization in an educational organization as a term of education quality improvement // RUDN Journal of Informatization Education. 2017. 14 (1). 76-82.

\title{
Bio Note:
}

Yatsenko Anna Igorevna, leading expert of department of statistics and accounting of the contingent of students of the Russian Peoples' Friendship University.

Contact information: e-mail: ann.yatsenko@mail.ru.

\section{ПРОЕКТ АВТОМАТИЗАЦИИ УПРАВЛЕНИЯ АДМИНИСТРАТИВНОЙ И МЕТОДИЧЕСКОЙ ДЕЯТЕЛЬНОСТЬЮ В ОБРАЗОВАТЕЛЬНОМ УЧРЕЖДЕНИИ КАК УСЛОВИЕ ПОВЫШЕНИЯ КАЧЕСТВА ОБРАЗОВАТЕЛЬНОГО ПРОЦЕССА}

\author{
А.И. Яценко \\ Российский университет дружбы народов \\ ул. Миклухо-Маклая, 6, Москва, Россия, 117198
}

В статье рассматривается практика применения информационных технологий в образовательном процессе в условиях информатизации образования. Актуальность рассматриваемого в статье вопроса подтверждается тенденцией повсеместного внедрения информационных технологий в образование как со стороны государства, так и со стороны бизнеса. Инструментарий информационных технологий позволяет в значительной степени повысить качество обучения. В связи с этим в статье приведены примеры использования различных информационных систем в целях администрирования образовательного процесса, рассмотрены их преимущества и недостатки, а также сформулирована проблема отсутствия интегрированной информационной системы. Вместе с тем развитие информационных технологий ориентировано в сторону Всемирной сети, куда имеет доступ обширная аудитория пользователей. Об- 
разовательные учреждения вовлечены в электронный процесс, поддерживаемый электронной средой развития образования. В результате исследования вышеуказанной проблемы и анализа перечисленных тенденций в статье предложен проект оптимизации управленческой функции образовательного учреждения путем использования интегрированной информационной системы в сети интернет.

Ключевые слова: информационные технологии, информационная система, информатизация образования, образовательный процесс, образовательное учреждение, электронная среда

\section{История статьи:}

Дата поступления в редакцию: 2 ноября 2016

Дата принятия к печати: 29 ноября 2016

\section{Для цитирования:}

Яценко А.И. Проект автоматизации управления административной и методической деятельностью в образовательном учреждении как условие повышения качества образовательного процесса // Вестник Российского университета дружбы народов. Серия «Информатизация образования». 2017. Т. 14. № 1. С. 76-82.

\section{Сведения об авторе:}

Яценко Анна Игоревна, ведущий специалист отдела статистики и учета контингента студентов Российского университета дружбы народов.

Контактная информация: e-mail: ann.yatsenko@mail.ru. 